\title{
The reliability of product-specific eco-labels as an agrobiodiversity management instrument
}

\author{
Mariëtte van Amstel · Claar de Brauw • Peter Driessen • \\ Pieter Glasbergen
}

Received: 23 March 2007 / Accepted: 14 June 2007 / Published online: 20 July 2007

(C) Springer Science+Business Media B.V. 2007

\begin{abstract}
This paper seeks to understand why multinationals prefer to launch a label specific to their own product and examines how reliable these product-specific eco-labels are. A new methodology is applied to assess the extent to which eco-labels live up to claims about their contribution to conservation and the sustainable use of agricultural biodiversity. Product-specific eco-labels are considered as industry self-regulation and all three regulatory stages are studied: the planning, implementation and outcome stage. There are major differences between the product specific eco-labels in the degree in which agrobiodiversity management is part of the normative labeling schemes. Although there are some problems of reliability, such as transparency in the implementation stage and the monitoring in the outcome stage, the degree of reliability of product-specific labels is comparable with eco-labels of international labeling families. The conclusion is that only one of the productspecific eco-labels examined here is reliable when examined in the light of all three stages. The main reason why multinationals establish a product-specific eco-label instead of adopting one from an existing labeling family is that they want to profile themselves as distinct from other companies. The unique character of a product-specific label creates a market opportunity for them.
\end{abstract}

Keywords Agricultural biodiversity $\cdot$ Biodiversity management $\cdot$ Reliability $\cdot$ Eco-labels $\cdot$ Industry self-regulation

M. van Amstel ( $\square)$

Athena Institute for Research on Innovation and Communication in Health and Life Sciences,

Vrije Universiteit Amsterdam, De Boelelaan 1085, 1081 HV Amsterdam, The Netherlands

e-mail: mariette.van.amstel@falw.vu.nl

M. van Amstel · C. de Brauw · P. Driessen · P. Glasbergen

Copernicus Institute for Sustainable Development and Innovation, Universiteit Utrecht, P.O. Box

80.115, 3508 TC Utrecht, The Netherlands 


\section{Introduction}

With regard to agricultural biodiversity, the government in the Netherlands has defined a policy of 'stimulation instead of regulation' (Parliamentary Report II 2004/2005). Although the loss of agrobiodiversity is a relatively complex environmental problem, this government considers (stimulated) self-regulation of private actors as more obvious problem-solving, than command and control regulation. As we know, government stimulation of the private sector through subsidies for the sake of conservation or sustainable use does not necessarily lead to the desired effects, even when the rules are diligently followed (e.g., CBD 2001; Kleijn et al. 2001; Mayer and Tikka 2006). It is thus important to find out if there are other strategies that could potentially be effective. One of those possible strategies is regulation through the market.

An eco-label is a typical market instrument of food suppliers, which is found on a great many products in the Netherlands and other countries. Its purpose is to reduce the information asymmetry between the buyer and seller by providing information to a customer who takes an item's environmental performance into account when acquiring it (Gunningham and Grabosky 1998). Essentially, an eco-label attests to the producer's claim that the product has certain environmental qualities (De Boer 2003). Thus, an eco-label is a policy instrument that is intended to increase transparency in the market (Erskine and Collins 1997; Galarraga Gallastegui 2002). Environmental friendliness is a credence good. This means that the consumer cannot discern whether the producer's claim is based on facts or falsehoods. The purchaser can see, smell, touch, or taste the product but still cannot determine whether it really was produced in an environmentally friendly way (Loureiro et al. 2002; Nadaï 1999).

An eco-label is a form of self-regulation in industry for the public good. The literature gives ample evidence that self-regulation does not always have the intended effects. In the case of eco-labels, three explanations are usually given: eco-labels do not make the market transparent; eco-labels scarcely influence consumer behavior; and eco-labels have no influence on manufacturers (e.g., Erskine and Collins 1997; Nunes and Riyanto 2005; Leire and Thidell 2004; Karl and Orwat 2000).

One reason why eco-labels do not make the market more transparent is that the consumers do not have sufficient knowledge. Too few consumers have ever heard of eco-labels (Erskine and Collins 1997; De Boer 1997, 2003, Nilsson et al. 2004). Furthermore, consumers are not well enough informed about what eco-labels represent and thus about the environmental benefits they stand for (De Waart and Spruyt 2001; CCA 2004; Nilsson et al. 2004). Moreover, it is not easy for a labeling organization to provide clear information about the content of an eco-label, especially when the labeling scheme applies many different criteria (Brom 2000; Nunes and Riyanto 2005). That said, Leire and Thidell (2004) conclude that consumers make too little use of the available information. Then too, an abundance of eco-labels can cause confusion and thus disrupt the market. Nunes and Riyanto (2005) mention the Netherlands as an example of a country with too many eco-labels. Thørgenson (2000) identifies the problem as information overload, whereby eco-labels become invisible to the consumer. As Kirchhoff (2000) and the CCA (2004) point out, confusion arises when many labels make roughly the same claims and are thus no longer distinguishable from each other (Meeuwsen and Deneux 2002).

Another reason why eco-labels do not work as they should is that they apparently have a limited influence on consumer behavior. The preferences for environmental friendliness that the public indicates in surveys are not borne out in their actual shopping behavior (Peattie 2000). Other considerations such as price, quality, and consumption patterns may 
deter them from making an environmentally friendly purchase (e.g., Leire and Thidell 2004; De Boer 2003). To be fair, the public assumes that everything in the stores meets minimum environmental standards (CCA 2004). At the same time, various investigations indicate that consumers have no confidence in the eco-labels or green information (Peattie 2000; Thørgenson 2000; De Boer 2003; Erskine and Collins 1997).

Finally, the actual effect of eco-labels may be different than intended due to the role of the producers. Adherence to standards is the Achilles heel of self-regulation (e.g., Parker 2002; Gunningham and Rees 1997; Havinga 2006; King and Lenox 2000). Mechanisms to enforce self-regulation by companies are scarce. As Karl and Orwat (2000) note, it is tempting to call one's product environmentally friendly, even though that claim cannot be backed up. Peattie (2000) states that $60 \%$ of English advertising about sustainability is not based on facts. In contrast, there are also producers that do carry out environmental selfregulation but deliberately refrain from communicating this to the public, perhaps because environmental friendliness has a tree-hugging image among their target group (De Waart and Spruyt 2001).

The disparity between the actual and the intended effect of eco-labels raises questions about their reliability. The reliability of eco-labels is an underexposed area in the research literature; most research is focused on their effectiveness or credibility. The focus of the present study is precisely on that gap in knowledge. That is, it considers the capacity of a selling party - a producer of foodstuffs - to provide a purchaser with proof and guarantees that the labeling scheme of an eco-label is not only adhered to but also has a beneficial effect on the environment.

Another aim of the present study is to fill a second gap in knowledge. Frequently, research is done on eco-labels belonging to an existing 'international labeling family.' International labeling families are the eco-labels organized according to a certain method that appear in different countries. An example of a labeling family are the organic labels, such as EKO in the Netherlands, Agriculture Biologique in France, Biogarantie in Belgium, Bio-Siegel, Bioland and Naturland in Germany, Soil Association in the UK and the organic seal in the USA. Another example of an international labeling family are the labels based on Life Cycle Analysis, standardized in ISO 14040, with family members as European Eco-label in the EU, Milieukeur in the Netherlands, Nordic Swan in Scandinavia and Blue Angel in Germany. In contrast, the present study focuses on product-specific ecolabels that are placed on a market by a single multinational firm. The focus was narrowed to the Dutch market because eco-labels are often country-specific. Multinationals were selected in order to generalize from the findings of this study; the conclusions should be applicable to other countries where these companies operate and market their products under the same or a similar label. What makes these product-specific eco-labels interesting is that precisely these labels are presumed to contribute to the information overload confronting the public. This research seeks to answer two questions. First, how reliable are the product-specific eco-labels of multinationals that claim to stimulate agrobiodiversity, operating on the Dutch foodstuffs market? Second, why do producers choose to put their 'own' eco-label on the market?

\section{Analytical framework}

For this study, we define reliability as the capacity of the party producing and selling foodstuffs to provide both evidence and guarantees that the standards for agrobiodiversity set by an eco-label are effective. Hereby, we focus on a situation of information asymmetry 
between the buyer and seller. We see an eco-label as a form of self-regulation of industry and distinguish three stages of regulation-planning, implementation, and outcome stagein an organizational process of regulation (Coglianese and Lazer 2003; Stoeckl 2004). During these stages, the following variables of reliability play a role:

1. The agrobiodiversity performance standards that are incorporated in the labeling schemes van eco-labels (planning stage);

2. The distribution of responsibilities and information by way of certain legal principles of rule of law (planning stage and implementation stage);

3. Compliance with the standards set in the labeling scheme (implementation stage).

4. Measuring and monitoring the effects of the labeling scheme (outcome stage).

The first step is to analyze the standards couched in the charters of the eco-labels. With the Agrobiodiversity Management Yardstick (AMY) as an aid, we compare how eco-labels stimulate agrobiodiversity (Van Amstel et al. 2006). AMY is a classification tool distinguishing ten types of farming activities. Placing the standards set forth in the labeling schemes in these categories allows us to compare the schemes.

The second variable refers to the distribution of responsibilities and information among parties in the product chain and with respect to consumers. On the grounds of the principles of transparency (e.g., Gunningham and Rees 1997), separation of powers (Ogus 1995; De Graaff 1998), and participation (Nilsson et al. 2004), the buyer is assured that information is accessible and that there is a division of powers among different regulatory and supervisory authorities (OECD 2004). In that light, these three principles will be examined more closely here (Van Schooten-van der Meer 1997).

The third variable of reliability is the compliance behavior of parties in the product chain. We investigate how the risk of non-compliance is anticipated in the labeling schemes of the eco-labels.

It is important to measure the effectiveness of the labeling schemes, the fourth variable, notably because they do not necessarily have any consequences for agrobiodiversity, even when the standards have been met (Gunningham and Rees 1997; Kleijn et al. 2001). We investigated whether companies measure the effect of rules they themselves have imposed and/or whether these results have implications for a revision of the labeling schemes.

Finally, we conducted interviews with experts to find out why the producers prefer to place their 'own' eco-label on the market instead of joining up with an existing labeling family. The first step in this investigation consisted of desk research. We studied diverse documents such as annual reports, sustainability reports, newsletters, and fact sheets (Bonduelle 2003a, b; CG year unknown, 2005, 2006; FLO 2001, 2005a, b, LMC 2003a, b, 2006; SAN year unknown, 2005a, b). In addition, we conducted 13 semi-structured expert interviews. An expert was usually an employee of the multinational or someone from another organization with links to the eco-label. The interviews were either recorded on tape and then transcribed or, in a few cases, done in writing. Before processing the interviews, the texts were made anonymous.

\section{Selection of cases}

The original population of product-specific labels comprised some 20 labels. Several selection criteria were formulated to select the cases. The population was initially delimited by requiring the label to be based on a scheme covering the production method. Thereby, certain labels were excluded: labels indicating that money is donated to a foundation; labels 
stating that a product complies with religious dietary laws; and labels pertaining to the packaging. The second delimitation, that the eco-label has to appear on the package, means that the label could play a role in the consumer's decision to buy the product. Third, the label has to refer explicitly to environmental friendliness, as judged by the wording. We looked for words such as organic, environmentally friendly, and green (Van der Meulen 2003). Having applied these criteria, we were left with the following labels (and the multinationals they belong to):

- Agrofair is a Dutch importer and distributor of tropical fruit, providing various European countries with fruit from South America and Africa. Agrofair sells the fruit by the brand name Oké, so that the products also bear an Oké label.

- Albert Heijn is a Dutch supermarket chain with various house brands in its product line. Greenfields, one of its own brand names, has a label for beef and lamb products from Ireland and Northern Ireland (UK).

- Bonduelle is a French producer of processed vegetables. The products are grown in Europe and sold under the brand name Bonduelle. The label on the package bears a text claiming 'controlled environmentally friendly cultivation' (in Dutch) which is a variation on the original French eco-label "Agriculture Raisonnée.".

- Chiquita is a US importer of fruit that grows bananas in South America. Since September 2005, Chiquita has sold bananas bearing the sticker of the Rainforest Alliance (RFA).

- Jordan's Cereals is an English company selling granola bars and fruit bars under the brand name Jordan's. Farmers from the United Kingdom provide the raw materials for these products. A label printed on the package reads "Conservation Grade, Farming for Wildlife" (CG)

\section{Agrobiodiversity in labeling schemes}

The first criterion of reliability is whether the standards set by labeling schemes do in fact stimulate agrobiodiversity. In an earlier study (Van Amstel et al. 2007), we designed an AMY. Agrobiodiversity is a socio-political construct: the reason that this concept is defined, formulated and communicated is that some consider it of great importance to take actions to maintain and conserve agro-ecosystems, species or genetic resources. This yardstick aims to connect the abstract concept agrobiodiversity with concrete on-farm actions, a combination that we have called agrobiodiversity management.

Sartori (1991) gives a solution to avoid the pitfall of miscomparing when a concept with a high level of abstraction is interpreted differently in dissimilar concrete regimes. Sartori's solution is called the 'ladder of abstraction,' which is the blueprint of AMY. The ladder of abstraction is based on the idea of classification and distinguishes several levels of abstraction. Few abstract categories have large intra-class variation, while many concrete categories have large inter-class variation. To design AMY we organized an expert workshop with 12 ecological experts. They defined agrobiodiversity management categories (both designing their own categories and using existing categories of the CBD and a conference organized by the Dutch Ministry of VROM 2005) and connected them in the ladder of abstraction, as is shown in Fig. 1. On the fourth level of abstraction, they distinguished ten categories of farming activities that are indicative of agrobiodiversity management in accordance with eco-labels pertaining to the cultivation of crops in the Netherlands. On the fifth level, about 160 concrete agrobiodiversity performance measures were distinguished in these 10 categories. 


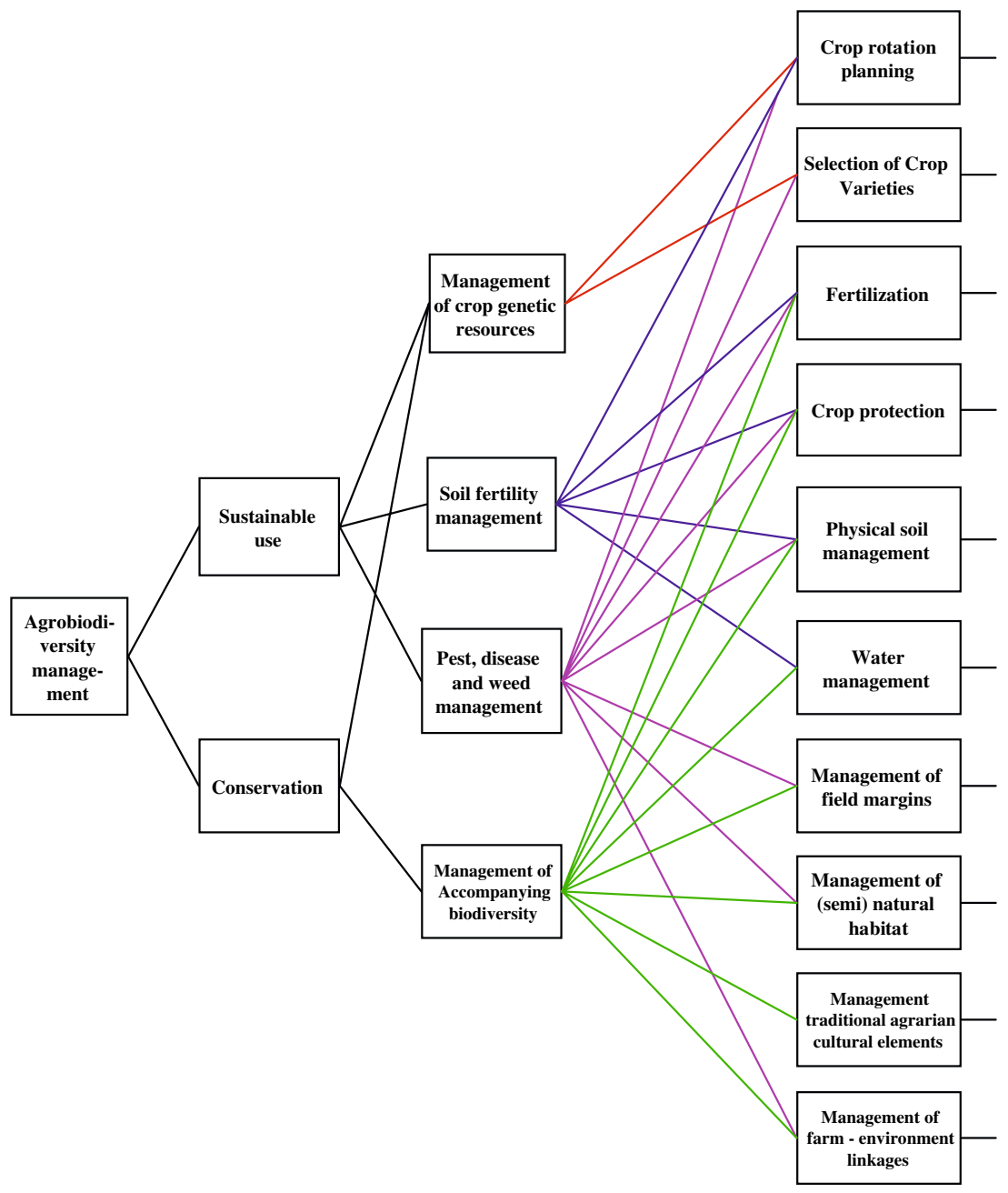

Fig. 1 The AMY, the first four levels of abstraction

These 10 categories are also used in the present study to identify and classify the differences in standards we found among the eco-labels, comparing the about 160 management measures with the labeling schemes. The labeling schemes of various products were studied: bananas (Oké and RFA), beef and lamb meat (Greenfields), and cultivated crops (Agriculture Raisonnée and CG). Since AMY is developed for arable farming in the Netherlands, we also included standards of eco-labels in our count that explicitly referred to biodiversity. Especially category 3-10 showed large overlap in formulation and structure with the eco-labels of international labeling families in the Netherlands, which are earlier assessed by us (Van Amstel et al. 2006, 2007).

As Fig. 2 shows, the five labels purport to stimulate agrobiodiversity in different ways. Bonduelle focuses specifically on sustainable use (covered by the first six types of farming activities), whereas Jordan's CG emphasizes the preservation of agrarian nature (the last four types). Chiquita RFA and Agrofair Oké have measures for both the preservation and the sustainable use of agrobiodiversity. There is a major difference in the amount of 


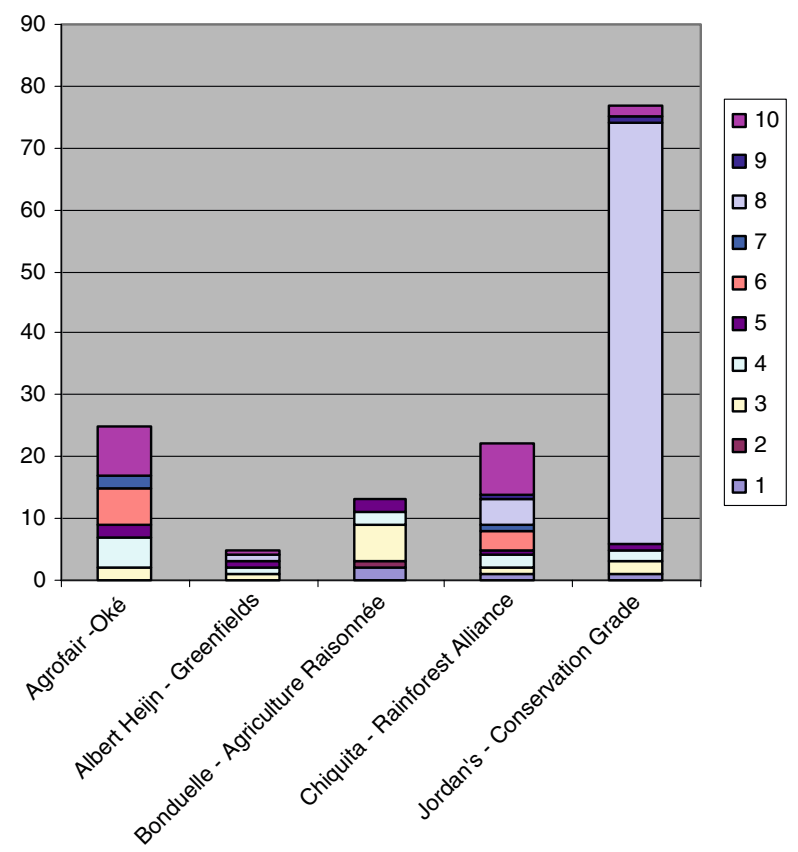

Fig. 2 Amount of agrobiodiversity performance standards per product-specific label per category farming activities. Numbers correspond with numbers in running text

standards of Jordan's CG, the only label specifically focusing on biodiversity, and the other labels. AMY has the widest coverage under the label Agrofair Oké (eight types) and Chiquita RFA (seven types). CG is the only label that has set quantitative standards for agrobiodiversity. For instance, it stipulates that $10 \%$ of the farmland under the scheme should be subject to habitat management.

In addition, we looked into the nature of the standards. Obligatory and optional standards as well as recommendations may be found in labeling schemes. For instance, an obligatory standard might contain the word 'must,' while an optional standard may state 'there must be either forf,' and a recommendation may contain the wording 'is advised.' Compliance with recommendations is entirely voluntary (Fig. 3).

The five labels also differ with respect to the force of their standards. All have obligatory norms while most also have optional standards or recommendations. Even only including obligatory standards, the leading position of CG is still undoubted.

\section{Principles of rule of law}

The literature on eco-labels gives guidance on reducing the information asymmetry between the producer/seller and the buyer. There is some overlap between these principles and those found in the literature of the philosophy of law concerning the protection of a weak party from a strong one within an asymmetrical power relation. Van Schooten-van der Meer (1997) selected three legal principles that are frequently cited in work on the philosophy of law. In subsequent research, she then applied these principles to self-regulation: 


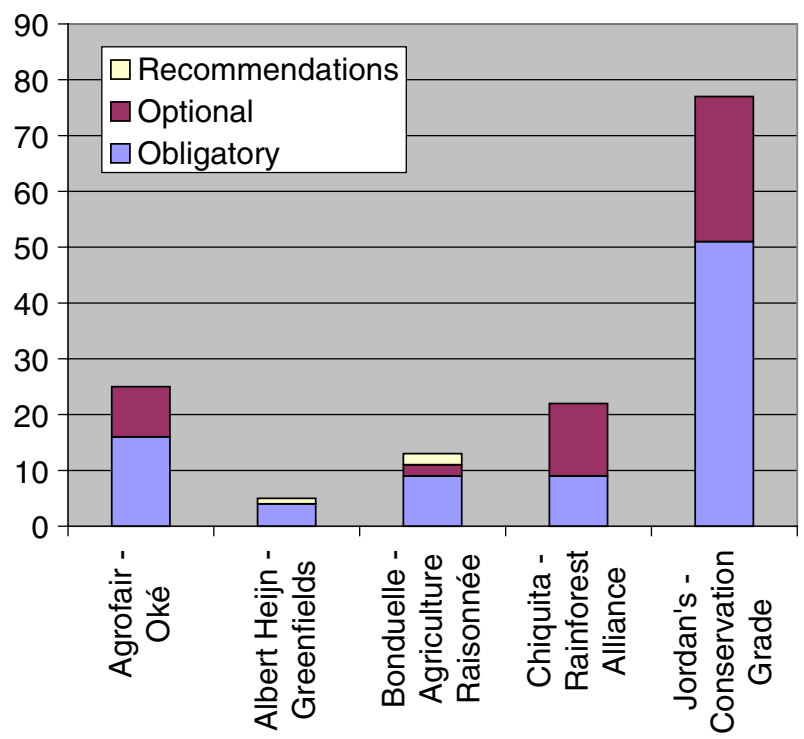

Fig. 3 The nature of standards of labeling schemes of the 5 product-specific eco-labels

- The principle of transparency. Transparency among the parties regarding standards, compliance with those standards, and the effects of doing so are important. Transparency can prevent non-compliance with self-regulation within the supply chain by ensuring that parties have access to knowledge about the behavior of other chain parties (traceability). On that basis, none can claim lack of information as an excuse (Gunningham and Rees 1997; Erskine and Collins 1997; Nilsson et al. 2004; Thøgersen 2000; De Boer 2003).

- The principle of the separation of powers. Independence, or the separation of powers, prevents a conflict of interests (De Graaff 1998; Erskine and Collins 1997; Kirchhoff 2000; Van der Valk and Van der Zeijden 2002). Separation of powers means a clearly articulated division of responsibilities among different supervisory, regulatory, enforcement and executory authorities (OECD 2004).

- The principle of participation. Nilsson et al. (2004) point out that commitment by stakeholders enhances the credibility of an eco-label. When parties formulate rules for themselves, they will be more inclined to comply with them (Gunningham and Rees 1997). Drawing NGOs into the standardization process can increase public support for regulation.

These legal principles have been operationalized for eco-labels in terms of good governance. Regarding the principle of transparency, we investigated the extent to which the information is transparent. Concerning the principle of the separation of powers we examined how the various responsibilities are distributed. With respect to participation, we asked whether or not-and if so, which-parties in the product chain and NGOs are involved in setting the standards for a labeling scheme.

\section{Transparency}

For all five eco-labels, we found that the producer provides general information about the ecolabel (see www.agrofair.nl, http://www.fairtrade.net, www.maxhavelaar.nl, www.ahgreenfields.nl, www.bonduelle.nl and www.bonduelle.com, www.chiquita.nl, www.chiquita.com, 
www.rainforest-alliance.org, http://www.conservationgrade.co.uk, www.Jordan'scereals.com, all retrieved 21 July 2006). Moreover, we found that Agrofair and Chiquita have posted the labeling schemes on their own websites. The labeling schemes of Greenfields, Bonduelle and CG may be obtained indirectly: for Greenfields on the websites www.lmcni.com and www.bordbia.ie; the labeling schemes of Bonduelle and $\mathrm{CG}$ are available upon request.

None of the eco-labels provide information on compliance with the labeling schemes. That kind of information is considered confidential. Furthermore, according to one interviewee, the consumers have no interest in this information. All the consumer needs to know is that compliance is monitored. The only one of these schemes that does give some insight into monitoring of compliance is $\mathrm{CG}$, which makes available the manuals used by the inspectors.

The RFA provides general information on the environmental performance of the label. The alliance has published research on this matter on its website (www.ra.org, retrieved 9 August 2006). CG has posted material on both the general effects of the eco-label and the effects that have been measured on demonstration farms (www.conservationgrade.co.uk, www.farmedenvironment.co.uk, both documents retrieved on 9 August 2006). The other eco-labels do not give any information about environmental impact.

Separation of powers

Kirchhoff (2000) differentiates exogenous from endogenous labels. Exogenous labels are subject to control by an independent third party (certification body), whereas endogenous labels are self-formulated environmental claims. With the aid of the 'certification triangle' of De Graaff (1998), as depicted in Fig. 4, we can analyze the structure of an exogenous label.

Each of the bodies has a different set of responsibilities. The standardization body designs and develops the labeling scheme that the seller/producer has to comply with. The certification body audits and certifies the seller. The accreditation body makes sure that the certification body is really independent, based on Guideline 65 of the International Organization for Standardization (ISO) and European Norms (EN) 45011. The continuous arrows in Fig. 2 indicate a regulatory relation (contract), while the dotted arrows indicate a form of interaction (label on a product, written communication, meetings, or participation). The

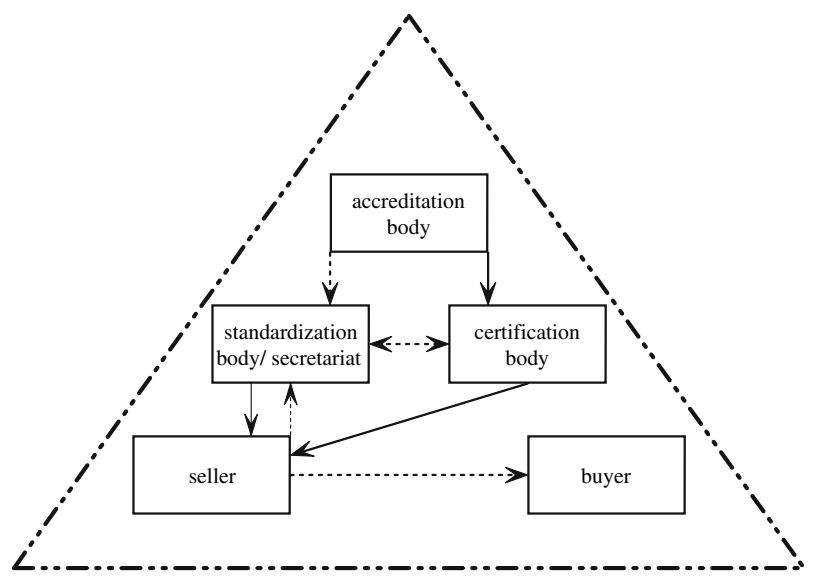

Fig. 4 Certification triangle, based on De Graaff (1995) 
seller communicates with the buyer about the product that bears the eco-label or certificate. In some cases, a seller can be part of the standardization body or can advise the standardization body. Both the standardization body and the certification body have to agree on how to implement the standards. This dotted arrow indicates lines of coordination between the standardization body and the certification bodies. They need coordination when setting standards and when making arrangements on how to inspect companies for compliance with the norms.

If we were to draw a diagram depicting endogenous labels, it would be simpler in design, since it would contain only two parties: a seller and a buyer. The seller himself would then guarantee the buyer that the product is environmentally friendly.

Only one of the five product-specific eco-labels of the multinationals is an endogenous label. It is Bonduelle's agriculture raisonnée label. Here, the endogenous status means that Bonduelle itself is in charge of the labeling scheme. Bonduelle contracts the farmers; Bonduelle's liaison officers monitor compliance by farmers; and Bonduelle takes care of the label for the package.

The other four labels are exogenous. As it turns out, Agrofair's Oké label is the same as that of the Fairtrade labeling family, of which Max Havelaar is the labeling organization. Oké does not add any content to the Fairtrade label. Underlying Greenfields are the labeling schemes of two organizations: the Livestock and Meat Commission (LMC) for the United Kingdom; and Bord Bia for Ireland. The Greenfields packaging does not bear the labels of either of these organizations, so the links are invisible. The eco-label that Albert Heijn and Jordan's use on their products is also accredited. That is not the case for the eco-labels that Agrofair and Chiquita use, though. Both Fairtrade and RFA are currently working on becoming accredited labels in the future. With the exception of the Bonduelle label, the four other labels are used by other companies outside the Dutch market. In the course of our investigation, the RFA label was also adopted by another producer in the Netherlands. Thus, labels that appear to be product-specific on one particular market are not necessarily product-specific when more countries are taken into account.

\section{Participation}

Four of the five labeling schemes-the exception is Bonduelle-have been developed in consultation with independent third parties. For two labels, namely Fairtrade and RFA, that other party is the ISEAL Alliance (2006), and both labels endorse its Code of Practice. It states, among other things, that the organizations setting the standards form a cross-section of the relevant parties. They are representative in terms of the subject matter and the geographical area where the standards apply. For three labels — namely Fairtrade, RFA, and LMC - the schemes are also subjected to a round of public consultation in which anyone can comment on the labeling scheme. This procedure is a bit less extensive for CG. The standards of that scheme are set by a consultancy firm, the Farmed Environment Company. Subsequently, the labeling scheme is submitted for approval to an independent committee consisting of farmers, academics, and members of civil society organizations.

\section{Comparison of the labels}

These three principles - transparency, independence, and participation-underpin the organization and implementation of the labeling process of the four exogenous eco-labels. It is important to them for the monitoring body to be objective. A common problem is that the transparency has limits. General information and lists of standards are easily accessible 
(i.e., the planning stage is transparent). In contrast, information on measuring the outcomes (i.e., on the outcome stage) is only available in incidental cases. Information on compliance with the standards (the implementation stage) is scarce.

The only principle endorsed by the endogenous label is transparency. We found no indication of a separation of powers or of participation in the development of its labeling scheme.

\section{Compliance}

Farmers' compliance behavior cannot be investigated by conducting a literature study and expert interviews. Basically, that is because these sources do not yield data on compliance. For instance, they do not reveal priorities for enforcement, how many checks were made, the kind of violations observed, or which sanctions were imposed. We have therefore narrowed the range of our analysis. It is focused on the likelihood of compliance, in light of the content of the labeling schemes. The methodology for this analysis is based on the 'Table of 11' (Van Erp and Verberk 2003). The Table of 11 depicts 11 dimensions that play a role in compliance by a target group. Each dimension is also associated with risks of noncompliance (Table 1).

The Table of 11 distinguishes two dimensions of compliance, spontaneous and enforced. Farmers who comply spontaneously follow the rules of self-regulation by their own volition. Alternatively, they may follow the rules because they face inspections or sanctions.

\section{Spontaneous compliance}

All of the eco-labels take measures to ensure that members of the target group (T1) are acquainted with the rules. The most thorough of the four in this respect is LMC, the organization behind Greenfields. LMC requires farmer to endorse the labeling scheme; by signing, they affirm that they have read and understood the standards.

In addition, all of the eco-labels ensure that compliance will be advantageous to the farmers (T2). For instance, farmers can sell their product above the market price. In this regard, one interviewee saw room for improvement in $\mathrm{CG}$, as price fluctuations can sometimes wipe

Table 1 Risks non-compliance identified with the Table of 11

Risks of non-compliance for the dimensions of spontaneous compliance

$1 \quad$ Non-compliance by farmers due to unawareness of standards and lack of clarity in standards

2 Non-compliance is advantageous to farmers in terms of time, money, and trouble. The financial barrier may be attributed to both the production method and the cost of certification

3 Farmers consider standards of the eco-label to be unreasonable

$4 \quad$ Farmers are not willing to conform to authority of SI/CI

5 Behavior of farmers is not sanctioned by unauthorized others (performing informal checks)

Risks of non-compliance for the enforcement dimensions

6 Little perceived chance that informally discovered violations will be reported to auditors (informal chance of being reported)

7 Little perceived chance of inspection after committing a violation (chance of control)

8 Little perceived chance of discovery of a violation upon inspection by auditor (chance of detection)

9 Little perceived chance of additional inspection after discovery of violation (chance of selection)

10 Little perceived chance of incurring sanction after discovery of a violation (chance of sanction)

11 Little harm by the sanctions and additional disadvantages of sanctioning (sanction type) 
out the margin. Fairtrade offers a financial bonus for implementing the standards from the labeling scheme (FLO 2001). Farmers are guaranteed that Bonduelle and Albert Heijn will buy their products; alternatively, they achieve higher levels of operational efficiency when affiliated with RFA and Fairtrade.

Comparison of the eco-labels suggests some difference with respect to how reasonable the standards are (T3) and how willing the farmer would be to comply with the authority (T4). However, CG ranks highest on both points. Under this scheme, the farmers have to write a motivation plan specifying individual targets for their own farm. Jordan's then selects its farmers on the basis of their plans.

Finally, there is greater chance of spontaneous compliance when the technicians doing the monitoring are not official inspectors (T5). Scientists and NGOs have conducted various studies on the eco-labels. Recently, a French investigation was published that was critical of the results of Fairtrade (Jacquiau 2006). The results of research on Bonduelle show a more diverse picture. An investigation by the environmental organization Milieudefensie (Ende and Tielens 2006) gives Bonduelle a good report card, whereas the consumer organization called Goede Waar en Co is critical of the Bonduelle label (www.goedewaar.nl, retrieved 23 August 2006). Two other labels, Jordan's and Chiquita, were also scrutinized by this consumer organization, while Greenfields was assessed by the animal welfare society (www.dierenbescherming.nl, retrieved 23 August 2006). Various investigations with negative outcomes have been published on Chiquita (Deutsche Gesellschaft für Technische Zusammenarbeit 2001; Gallaghar and McWhither 1998; Stein 2001; Swedish Society for Nature Conservation 2005; Lustig 2004). The five dimensions of spontaneous compliance are set forth in Table 2.

\section{Enforcement}

Each of the five labels has a regime for monitoring and imposing sanctions. According to the interviewees, though, the labeling organizations do not always get the results of unofficial inspections or, if they do, that knowledge does not always lead to adjustments (T6). RFA and Fairtrade are the only ones that take comments about the farmers as grounds to carry out extra inspections (SAN 2005a). Bonduelle uses the positive outcomes of research as promotional material; the firm indicates that it disagrees with the negative outcomes in publications. Albert Heijn discusses research findings with NGOs, but it is unclear whether or not the discussion leads to action or improvement.

With respect to announced inspections (T7), the monitoring frequency for the four exogenous labels - once every 12 or 18 months-is low. With such a gap, a farmer could operate in a way that does not correspond with the labeling scheme. Then, when the time comes for inspection, the farmer could show the auditor what he would like to see instead of the real situation. Such evasive behavior is less likely for a number of requirements of CG and RFA. Obviously, habitats and buffer zones are not established in a day. It is possible, though, to conceal prohibited pesticides before the announced audit occurs. The monitoring frequency for Bonduelle is unclear but seems to be higher than for the exogenous ecolabels. Bonduelle has an agronomists services to provide the growers with guidance and crop surveillance, in combination with monitoring in all stages of the production process. This agronomist service has actually taken over some of the executive responsibilities that traditionally belong to the grower. But the farmers have an extra incentive to comply. Not only does the firm's agronomist service pick up the bill for these inspections, but the firm also selects the farmers with whom it wants to enter into a contract. Indeed, as the interviewee from Bonduelle stated, only the very best farmers are offered a contract. 
Table 2 Spontaneous dimensions of compliance per eco-label

\begin{tabular}{ll}
\hline Eco-label & Institutional guarantees for dimensions of spontaneous compliance \\
\hline Agrofair-Oké & (T1) - Some of the standards indicate how monitoring takes place \\
(T2) - Higher price and financial bonus for products, so that the farmers do not \\
go bankrupt; more efficient farms, no charge for certification, farmers are \\
stockholders of Agrofair \\
(T3) - Voluntary scheme, civil society organizations are involved in setting \\
standards \\
(T4) - Opportunities for control and obligations for rapportage are set forth in \\
contract. \\
(T5) - Supply chain parties check on each other; Goede Waar en Co is posi- \\
tive, negative audit in French research
\end{tabular}

Albert Heijn-Greenfields (T1) - Farmer signs standards to affirm understanding; newsletters and extra information; standards indicate how monitoring takes place

(T2) - Purchase guarantee, fair price for costs incurred, knowledge about consumer preferences

(T3) - Voluntary scheme, market parties involved in setting standards

(T4) - Opportunities for control and obligations for rapportage are set forth in contract

(T5) - AH monitors itself, control of animal welfare moderately positive

Bonduelle-Controlled (T1) - Standards set forth in contract, explanation and consultation during conenvironmentally friendly tract negotiations, cultivation surveillance by agricultural extension services cultivation

(T2) —Purchase guarantee

(T3) - Voluntary scheme

(T4) - Opportunities for control and obligations for rapportage are set forth in contract

(T5) - Research by Milieukeur (positive) and Goede Waar en Co (negative)

Chiquita-Rainforest alliance

Jordans-Conservation grade
(T1) - Training for farmers, extra explanation and technical support by certifying body, newsletter Chiquita

(T2) - Higher price to compensate for costs, more efficient farms, knowledge of consumer preferences

(T3) - Voluntary scheme, civil society organizations are involved in setting standards

(T4) - Opportunities for control and obligations for rapportage are set forth in contract

(T5) - Certified farmers monitor each other; Chiquita and RFA are subject to many investigations by third parties,:Goede Waar en Co positive: American investigations negative

(T1) - Training for farmers, extra explanation possible, technical support

(T2) - Farmers usually get a higher price, stronger competitive position for processors

(T3) - Voluntary scheme, farmers are selected on basis of their motivation, farmers are involved in setting standards

(T4) - Opportunities for control and obligations for rapportage are set forth in contract

(T5) — Negative assessment by Goede Waar en Co.

The eco-labels train their auditors to identify violations when they carry out an inspection (T8). They also have checklists and interpretation documents for the labeling schemes. The method used by RFA is called triple checking. This means that the manager, employees, and documents are all checked at the same time. The four exogenous eco-labels also conduct extra, unannounced inspections in the event that previous audits had turned up any irregularities (T9). 
All of the eco-labels penalize farmers who are found to be in violation (T10). Yet only two eco-labels have a system of sanctions that describe precisely under which conditions a particular measure would be imposed. Specifically, these are CG and Greenfields (CG 2005; LMC 2003a, b). But RFA and Fairtrade can also impose sanctions, namely by suspending or decertifying the farmer (T11). Table 3 gives an overview of the enforcement dimensions for each eco-label.

Comparison of the labels

We did not assess the extent of actual compliance due to a lack of information. One conclusion we could draw is that all of the eco-labels have specified institutional guarantees to reduce the chance of non-compliance. With respect to the dimensions of spontaneous compliance, we found that eco-labels put most effort into informing farmers of the standards (T1) and the advantages of compliance (T2). In addition, we found that inspections are also conducted by unofficial bodies (T5). Both RFA and Fairtrade take these results as grounds for holding extra inspections. For the rest of the labels, though, informal checks have little impact on compliance. Yet this does not mean that such checks would have no effect; they could undermine the credibility and public acceptance of an eco-label.

With respect to the institutional dimensions, the emphasis is on increasing the chance that a farmer will get caught (T8). The inspectors are trained and rotated, and inspection rounds are scheduled systematically. Nonetheless, it remains to be seen whether these efforts come to naught because of the low frequency of inspections. At a frequency of once or twice a year, fraud is an easy option for a farmer. Furthermore, the sanction policy is not very strict. The farmer almost always gets the chance to fix what was wrong. Alternatively, together with the certification body, the parties try to find a way to attain the desired situation. Compared to the other eco-labels, Jordan's has the most institutional guarantees.

\section{Monitoring outcome stage}

In this section, we discuss whether the environmental impact of an eco-label is monitored and, if so, what comprises such an auditing system. Systematic measurements increase the reliability of an eco-label.

The only label to systematically monitor environmental impact is CG. The Centre of Hydrology and Ecology carries out annual surveys of the biodiversity present on two demonstration farms (www.farmedenvironment.co.uk, retrieved 8 August 2006). These findings are also used in the process of setting standards and revising the labeling scheme.

The scheme the RFA uses to monitor environmental impact is less extensive. Due to a lack of funds, there is no systematic monitoring. Impact assessments are made at a small scale, though, for instance by trainees. According to the interviewee from RFA, the organization is aware that they should improve monitoring, and they recently received a subsidy to do so. Even so, the results will not be used as feedback in any efforts to adapt the labeling scheme. The reason is that RFA does not set any quantitative targets. Another organization, Conservation International, was commissioned by Chiquita to conduct comparative research on the effects of RFA by studying two farms, one certified by RFA, the other not. In light of the results, Chiquita decided to certify all of its own plantations.

No environmental impact studies are carried out by the Greenfields and Oké labels; Bonduelle has not provided any information on the subject. The results are summarized for each eco-label in Table 4 . One reason why the farmers contracted by these eco-labels are 
Table 3 Enforcement dimensions per eco-label

\begin{tabular}{ll}
\hline Eco-label & Institutional guarantees for enforcement dimensions (T6-T11) \\
\hline Agrofair-Oké & (T6) - Signals from supply chain parties about violations are investigated \\
(T7) - Annual audit; intention of audit depends on the risk of the production \\
sector \\
(T8) - Interview farmers and control bookkeeping, annually trained auditors, \\
no rotation \\
(T9) - Unannounced extra audits when signals on non-compliance are \\
received \\
(T10) - Up to a year for remediation; afterwards, suspension or \\
de-certification \\
(T11) - Suspension upon non-compliance, de-certification upon repeated \\
non-compliance or a lengthy period without showing progress
\end{tabular}

Albert Heijn-Greenfields

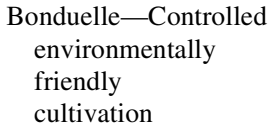

Chiquita-Rainforest alliance
(T6) - $\mathrm{AH}$ listens to the assessment of the label by the animal welfare group Dierenbescherming; own inspections have no consequences

(T7) - Annually announced control of bookkeeping, every 18 months an announced inspection of farm and livestock, annually possibly unannounced samples collected at $5-10 \%$ of the farms

(T8) - Accredited certifier, trained auditors, rotation of inspectors

(T9) —Possibly selection of farms for extra inspection

(T10) - Month allowed for remediation, afterwards suspension, contract with AH rescinded

(T11) - Duration of suspension depends on kind of violation

(T6) —Bonduelle uses positive assessment in promotional material

(T7) - Inspections by internal agrarian extension services, frequency unclear

(T8) - Control books and collect samples, no information on the auditors

(T9) - Possibly selection of farmers for extra inspections

(T10-T11) - Bonduelle is not required to buy products that do not meet the standards and can rescind the contract

(T6) — RFA responds to comments of farmers and complaints by other stakeholders

(T7) - Each year announced inspections

(T8) - Triple Checking System, rotation of auditors, trained auditors

(T9) - Unannounced extra inspections when complaints are received

(T10-T11) - For certification, the farmer must meet $80 \%$ of all standards, $50 \%$ of the standards for each principle, and $100 \%$ of the critical standards; when standards are not met, evaluation is made to determine if problem is systematic or temporary; period to resolve the problems between 6 months and 2 years; sanction consists of losing the certificate

(T6) - No research results known at CG.

(T7) - Annually announced inspections for the general requirements; per year, $20 \%$ of the farms inspected for habitat

(T8) - General requirements inspected by trained inspectors of accredited body on the basis of a specific auditing scheme; still no rotation of inspectors; inspection of habitats by independent ecologists on the basis of a specific auditing scheme

(T9) -Extra inspections if the habitats do not pass; so far, no need to re-inspect farm for general requirements

(T10-T11) - General requirements for system of minor and major problems that could lead to rescinding the contract with the processor; habitats that still do not pass after re-inspection also lead to rescinding the contract with the processor 
Table 4 Auditing environmental impact per eco-label

\begin{tabular}{llll}
\hline Eco-label & Audit & Frequency & Feedback \\
\hline Agrofair-Oké & No & - & - \\
$\begin{array}{l}\text { Albert Heijn-Greenfields } \\
\text { Bonduelle-Controlled environmentally } \\
\quad \text { Nriendly cultivation }\end{array}$ & No & - & - \\
$\begin{array}{l}\text { Chiquita-RFA } \\
\text { Jordans-CG }\end{array}$ & Yes & Incidentally & No, used in promotional material \\
\hline
\end{tabular}

not systematically audited is the assumption that if the standards are met, the anticipated effects will logically follow. Thus, there will be no need to measure them. But there are other reasons too: there might not be enough money, or the effects might not be measurable. However, both RFA and Fairtrade are working on ways to improve their monitoring system. In the future, environmental impact might well be measured at Fairtrade.

\section{Reasons to adopt a product-specific label}

The second research question in the present study asks why firms choose to communicate their environmental friendliness by means of a product-specific eco-label. To answer that question, we first consider the producers' motivations. Then we discuss their opinions on whether the introduction of yet another eco-label might confuse the consumers.

The interviewees motivate their choice of a label in two ways: with arguments in favor of introducing their 'own' eco-label; and arguments against using eco-labels from existing labeling families.

The most prevalent reason to use a product-specific eco-label is in order to distinguish a particular product from other products. Bonduelle wants to use the label to let consumers know that Bonduelle does something that the other firms do not. Similarly, Jordan's uses the CG label to distinguish itself from other companies. And Chiquita, after working with the RFA for 14 years, has decided to let the consumers know of its link with this label in response to the competition on the West European market. In this way, the public can tell a Chiquita banana from other bananas. Agrofair has designed the Oké label to differentiate itself from other producers aligned with Fairtrade. Yet there are other arguments in favor of an eco-label, be it product-specific or part of a family. The reason why environmentally friendly products yield higher profits is that consumers are willing to pay more for a product that is sustainably produced. And a company can advertise under its own eco-label to improve its image or customer loyalty. Consider the case of Chiquita, which started to work with the RFA when the amount of negative publicity on the company kept increasing. Jordan's chose to sign on with an eco-label that is concerned with biodiversity because, as consumer research has shown, the British consumer is mainly interested in an eco-label that promotes wildlife.

A number of interviewees gave some reasons why a company would not choose to affiliate with an existing label. First, an existing eco-label is not a distinguishing feature. This concern is evident among the producers using the existing label Fairtrade. As a case in point, Agrofair's 'own' Oké logo presents the Fairtrade standards in a positive light. The producer of Tony's Chocolonely, in contrast, puts a different slant on the Fairtrade standards: its 'own' label states that the product is ' $100 \%$ slave-free,' as guaranteed by Max Havelaar. Thus, while the claims of both companies are based on Fairtrade certification, the Oké and 'Slave-free' logos differentiate the two product lines. Second, it is said that existing 
Table 5 Reasons to prefer an eco-label of their own over an existing eco-label

\begin{tabular}{|c|c|c|}
\hline Eco-label & Reasons in favor of an own label & Reasons against an existing label \\
\hline Agrofair-Oké & Differentiation & Does not differentiate \\
\hline Albert Heijn-Greenfields & Consumer preference, more profit & $\begin{array}{l}\text { Evokes fear in consumer about } \\
\text { normal product line }\end{array}$ \\
\hline $\begin{array}{l}\text { Bonduelle-Controlled } \\
\text { environmentally friendly } \\
\text { cultivation }\end{array}$ & Differentiation, customer loyalty & $\begin{array}{l}\text { Evokes fear in consumer about } \\
\text { normal product, organic label } \\
\text { not feasible }\end{array}$ \\
\hline Chiquita—Rainforest Alliance & $\begin{array}{l}\text { Differentiation, RFA active on } \\
\text { the subject and directed toward } \\
\text { problem-solving }\end{array}$ & $\begin{array}{l}\text { Organic label not feasible, } \\
\text { in the early 1990s the Fairtrade } \\
\text { standards were not available } \\
\text { for bananas }\end{array}$ \\
\hline Jordans-Conservation grade & $\begin{array}{l}\text { Differentiation, responding to } \\
\text { specific preference of consumers }\end{array}$ & Organic label not feasible \\
\hline
\end{tabular}

labeling families might possibly have a negative spin-off on conventional products that do not bear an eco-label. For instance, the interviewee from Bonduelle noted that by including organic foods in Bonduelle's product line, consumers might get the idea that 'normal' Bonduelle products are not environmentally friendly. One reason to decide against organic production is that producers feel they could not possibly apply the large-scale industrial methods that organic production would entail. Table 5 presents these concerns for each eco-label.

Regarding the confusion that the diverse eco-labels create for the public, the most important concern for producers with their own eco-labels, according to the interviewees, is that the consumer should recognize the eco-label and have a positive response to it. Whether or not the consumer is well informed about the meaning of the eco-label is considered less relevant. Thus, the producer is hardly concerned about whether its own eco-label confuses the public or not. Actually, the producer has an interest in keeping the public from being able to compare its own eco-label with other eco-labels. Indeed, the comparison might not turn out well for the own label.

\section{Conclusions}

The aim of this study was to find out whether or not product-specific eco-labels stimulation agrobiodiversity are reliable and why producers prefer product-specific eco-labels. We cannot demonstrate that any of the five eco-labels examined here should be considered reliable for all three stages of self-regulation. The missing evidence is particularly acute for the implementation stage, in the absence of documentation on how the participants in the ewco-label schemes have complied with the standards. In fact, for most of these eco-labels, we could not demonstrate the impact on biodiversity either. There is usually not enough money available to audit farmers' performance, so the effects on the environment are not monitored but assumed.

Comparing the five eco-labels, the most reliable eco-label turns out to be CG, which has also included quantitative agrobiodiversity standards in the labeling scheme. This eco-label selects participants on the grounds of their motivation and the most far-reaching distribution of responsibilities among independent third parties. Moreover, it is the only one of the eco-labels to annually carry out a systematic audit of performance and use the results as a feedback loop when making adjustments in the labeling scheme. 
With respect to standards for agrobiodiversity performance, three labels-namely Oké, RFA, and Bonduelle - are roughly equal. Greenfields has adopted the lowest agrobiodiversity performance standards. Regarding the procedural requirements for reliability, the middle bracket consists of Oké, RFA, and Greenfields. Arrangements are made to distribute responsibilities among independent third parties, and there are various guarantees of compliance with the labeling schemes. However, environmental performance is not systematically audited. Bonduelle, the only endogenous eco-label, trails behind the rest. It does not arrange for independent audits. Nor does it compensate for this lack of objectivity by conducting its own inspections. Thus, there is no subsequent feedback loop for the sake of setting standards for the labeling scheme.

This study shows that it is in principle possible for food producers to regulate a public good, specifically agrobiodiversity, through industry self-regulation and to integrate that good in the food supply chain. Apart from the finding that eco-labels are not reliable for all stages, the study also reveals that their capacity to reduce the information asymmetry between the seller and the consumer is very limited. This is also clear from the reasons that multinationals give for choosing to operate under an eco-label of their own rather than one from an existing labeling family. Their rationale is not that they want to provide the consumer with better information, and that their own label can do that best. Rather, they believe that for marketing reasons a company needs a way to distinguish itself from its competitors. Thus, they argue, companies have to be able to put a label of their own on their entire product range.

It seems that their main objective is not to reduce the information asymmetry by informing consumers about their products. Actually, the information they provide is contextspecific in a sense that it is geared entirely to a producer with a certain knowledge level, understanding of and experience with production processes. It is not directed at the consumer in the shop at all, who is the end-user of the product. Consumers are left in the dark about how the environmental effects of one eco-label compare to those of another, as they do not have information about the entire production-process of suppliers.

It remains to be seen if eco-labels are really so suitable as instruments of governance for the conservation and sustainable use of agrobiodiversity. After all, the results of the product-specific eco-labels and the reliability weaknesses are comparable to the weaknesses of eco-labels of international labeling families (Van Amstel et al. 2006). And if so, it is unclear just how eco-labels might be made more robust and by whom.

In our opinion, the strength of the eco-labels lies in their capacity to translate an abstract notion like biodiversity into terms relevant to a specific supply chain. Their great potential lies in the possibility to take concrete measures through that chain to stimulate agrobiodiversity. In that regard, eco-labels would seem to have a reasonable chance of success within a chain and through business-to-business communication, at least if we can assume that eco-labels are reliable. This does not mean, however, that the eco-label is also a suitable means to resolve the problem of information asymmetry between the producer and the consumer. Meanwhile, the eco-labels are not making any mutually comparable information about environmental impact available to consumers. Until they do, these instruments will not be up to the task of reducing information asymmetry.

In order to improve the quality of eco-labels, governments would have to set standards for labels. Preferably, this would occur at the level of the European Union, for the sake of a broad, level playing field and to assure equality and interchangeability among the Member States. Those standards should ensure that two conditions are met. First, in general, there must be transparency on compliance with the labeling schemes. For instance, annual reports should be published giving figures for audits carried out, enumerating the violations found, sanctions imposed, and cases taken to court. This information is currently published 
for the organic labels under EU regulation. Second, and more specifically, efforts should focus on monitoring the environmental impact and on putting together mutually comparable information on these effects for consumers. From a legal standpoint, this would entail defining the concept of the eco-label in terms of regulation. That means reserving usage of the word by giving it trademark status and setting a few criteria for its application. Before any such steps could be taken in a real social context, however, some obstacles would have to be overcome. In the present situation, the parties offering business-to-business eco-labels for consumer products do not seem to have any interest in making labels mutually comparable, nor in focusing on a label's environmental impact.

\section{References}

Bonduelle (2003a) Bonduelle supply charter. Bonduelle, Lille-Villeneuve d'Ascq Cedex

Bonduelle (2003b) Audit guide for the bonduelle supply charter. Bonduelle, Lille-Villeneuve d'Ascq Cedex Brom FWA (2000) Food, consumers concerns, and trust: food ethics for a globalizing market. J Agric Environ Ethics 12:127-139

Coglianese C, Lazer D (2003) Management-based regulation: prescribing private management to achieve public goals. Law Soc Rev 37(4):691-730

CBD (2001) Handbook of the convention on biological diversity. secretariat of the convention on biological diversity. Earthscan Publications, London

CCA, Commissie voor Consumentenaangelegenheden (2004) Advies: Keurmerken en duurzame ontwikkeling, SER, Den Haag. [NB: Advise: Eco-labels and Sustainable Development]

CG, Conservation Grade (year unknown) Inspector Guidance notes for the conservation grade standard of Conservation Grade Producers Ltd. Conservation Grade, North Yorkshire

CG, Conservation Grade (2005) Conservation grade — farming for wildlife. Conservation Grade, North Yorkshire

CG, Conservation Grade (2006) Guidance Notes for habitat assessor-conservation Grade Producers Ltd. Conservation Grade, North Yorkshire

Deutsche Gesellschaft für Technische Zusammenarbeit (2001) Analysis of the possibilities for the utilization of certification and labeling systems as an option for the promotion of agricultural biodiversity. Deutsche Gesellschaft für Technische Zusammenarbeit, Esborn

De Boer I (1997) De milieukeur gekeurd, vergelijking met de Blaue Engel en de Nordic Swan, VROM, Den Haag [NB: The milieukeur assessed, comparison with Blaue Engels adn the Nordic Swan]

De Boer J (2003) Sustainability Labeling schemes: the logic of their claims and their functions for stakeholders. Business Strategy Environ 12:254-264

De Graaff V (1998) Private certification in a governance context. An assessment towards communicative governance. Dissertation, Eburon Publishers, Delft

De Waart S, Spruyt D (2001) Keur of Willekeur: een inventarisatie van ideële keurmerken en groene beeldmerken, Alternatieve Konsumentenbond, Amsterdam [NB: label or unfairness: an inventory of idealistic labels and green symbols]

Ende A, Tielens C (2003) Onderzoek milieudefensie: Duurzame bedrijven in Nederland? Artoos Nederland BV, Rijswijk. [NB: Research Dutch Friends of the Earth: Sustainable companies in the Netherlands?]

Erskine CC, Collins L (1997) Eco-labeling: success or failure? Environmentalist 17:125-133

FLO, Fairtrade Labelling Organisation (2001) Fairtrade Bananas-how the system functions. FLO, Bonn

FLO, Fairtrade Labelling Organisation (2005a) Generic fairtrade standards for small farmers'. Organisations, FLO, Bonn

FLO, Fairtrade Labelling Organisation (2005b) Fairtrade standards for bananas for small farmers'. Organisations, FLO, Bonn

Galarraga Gallastegui I (2002) The use of eco-labels: a review of the literature. Eurp Environ 12:316-331

Gallaghar M, McWhither C (1998) Chiquita secrets revealed, cincinnati enquirer, May 3, 1998

Gunningham N, Rees J (1997) Industry self-regulation: an institutional perspective. Law Policy 19:363-414

Gunningham N, Grabosky PN (1998). Smart regulation: designing environmental policy. Oxford Clarendon Press, Oxford

Havinga T (2006). Private regulation of food safety by supermarkets. Law Policy 28:515-533

Jacquiau C (2006) Les coulisses du commerce équitable: Mensonges et vérités sur un petit business qui monte. Mille et une nuits, France 
Karl H, Orwat C (2000) Economic aspects of environmental labelling. In: Folmer H, Tietenberg T (eds) The International Environmental and Resource Economics 1999/2000 Edgar Elgar Cheltenham UK, Northampton, USA

King AA, Lenox MJ (2000) Industry self-regulation without sanctions: the chemical industry's responsible care program. Acad Manage J 43:698-716

Kirchhoff S (2000) Green business and blue angels. Environ Res Econ 15:403-420

Kleijn D, Berendse F, Smit R, Gilissen N. (2001) Agri-environmental schemes do not effectively protect biodiversity in Dutch agricultural landscapes. Nature 413:723-725

Leire C, Thidell A (2004) Product-related environmental information to guide consumer purchases-a review and analysis of research on perceptions, understanding and use among Nordic consumers. J Clean Prod 13:1061-1070

LMC, Livestock, Meat Commission (2003a) FQAS standard, northern ireland beef \& lamb quality assurance scheme. LMC, Lisburn

LMC, Livestock, Meat Commission (2003b) Rules, northern ireland beef \& lamb quality assurance scheme. LMC, Lisburn

LMC, Livestock and Meat Commission (2006) Northern Ireland beef and lamb on extensive promotion in the Netherlands. The Bulletin of the Livestock and Meat Commission, No. 1913, LMC, Lisburn

Loureiro ML, McCluskey JJ, Mittelhammer RC ((2002) Will consumers pay a premium for eco-labeled apples? J Consumer Affairs 36:203-219

Lustig T (2004) The search for the perfect banana. Swedish Society for Nature Conservation, Stockholm

Mayer AL, Tikka PM (2006) Biodiversity conservation incentive programs for privately owned forests. Environ Sci Policy 9:614-625

Meeusen M, Deneux S (2002). Een Babylonische keurmerkverwarring? LEI, Den Haag [NB: A Babylonic eco-label confusion?]

Nadaï A (1999) Conditions for the development of a product ecolabel. Eurp Environ 9:202-211

Nilsson H, Tunçer B, Thidell Å (2004) The use of eco-labeling like initiatives on food products to promote quality assurance-is there enough credibility? J Clean Prod 12(5):517-526

Nunes PALD, Riyanto YE (2005) Information as a regulatory instrument to price biodiversity benefits: certification and ecolabeling policy practices. Biod Conserv 14:2009-2027

OECD (2004) OECD Principles of Corporate Governance. Organisation for Economic Cooperation and Development. Paris

Ogus A (1995) Rethinking self-regulation. Oxford J Legal Stud 15:97-108

Parker C (2002) The open cooperation. Effective self-regulation and democracy. Cambridge University Press, Cambridge

Peattie K (2000) Golden goose or wild goose? The Hunt for the green consumer. Business Strategy Environ 10:187-199

SAN, Sustainable Agriculture Network (year unknown) Factsheet- the Rainforest Alliance. RFA, Costa Rica

SAN, Sustainable Agriculture Network (2005a) Sustainable agriculture standard with indicators. SAN, Costa Rica

SAN, Sustainable Agriculture Network (2005b) Additional criteria and indicators for banana production. SAN, Costa Rica

Sartori G (1991) Comparing and Miscomparing. J Theor Polit 3(3): 243-257

Stein N (2001) Chiquita, yes, we have no profits. Fortune 26 November 2001

Stoeckl N (2004) The private costs and benefits of environmental self-regulation: which firms have most to gain? Business Strategy Environ 13:135-155

Swedish Society for Nature Conservation (2005) SSNC reports Chiquita. SSNC News

Thøgersen J (2000) Psychological determinants of paying attention to eco-labels in purchase decisions: model to development and multinational validation. J Consumer Policy 23:285-313

Van Amstel MHJW, Driessen PPJ, Glasbergen P (2006) Eco-labeling and information asymmetry: a comparison of five eco-labels in the Netherlands. J Clean Prod (In Press) online available since October 6, 2006

Van Amstel MHJW, De Neve W, De Kraker J, Glasbergen P (2007) Assessment of the potential of eco-labels to promote agrobiodiversity. Ambio 36(3) (In Press)

Van Erp J, Verberk S (2003) Certificering als instrument van naleving van regelgeving, Expertisecentrum Rechtshandhaving, Den Haag [NB: Certification as an instrument for compliance with regulation]

Van der Meulen H (2003) Voedselveiligheid versus Voedseldiversiteit. In: Rougoor C, Van der Weijden W, en Bol P (eds) Voedselveiligheid tot (w)elke prijs? Essays en verslag van een conferentie. Ministerie van LNV, Den Haag [NB: Food Safety versus Food Diversity]

Van Schooten-Van der Meer J (1997) Regelvorming in de rechtsstaat. Dissertation, Twente University Press [NB: Rule-making in the State of Law] 
Van der Valk WD, van der Zeijden PT (2002) Keurmerken, erkenningsregelingen en certificaten; klare wijn of rookgordijn? EIM Onderzoek voor Bedrijf en Beleid, Zoetermeer [NB: labels, recognation-regulation and certificates: clear or smoke screen?]

VROM (2005) Boeren, bedrijven en biodiversiteit. Rapport en aanbevelingen, Conferentie 2 Maart 2005. 's-Gravenhage: Ministerie van Volkshuisvesting, Ruimtelijke Ordening en Milieu [NB: Farmers, Companies and Biodiversity. Report and Recommendations, Conference March 2, 2005] 